\title{
The Recent Protest Movements in Eastern Europe as an Indicator for Multiple Crises?
}

\author{
Tobias Spöri1 ${ }^{1, *}$, Felix Jaitner ${ }^{1}$ \\ 1 University of Vienna, Austria \\ * E-Mail: tobias.spoeri@univie.ac.at
}

\begin{abstract}
Since the outbreak of the financial and economic crisis in 2008, Eastern European countries have been affected severely by the crisis through intensified austerity measures, higher unemployment rates, and increasing dissatisfaction with democracy. Against this backdrop, the region has experienced several large-scale protest movements in recent years. The paper critically assesses the state of the art on political participation in Eastern Europe. Special attention is paid to the still underplayed effects of the global economic crisis. Subsequently, the question is raised whether the increased number of protests indicates a deeper societal crisis. Thereby, the authors conclude, Eastern Europe serves to a certain extend as a trendsetter for similar developments in other parts of Europe.
\end{abstract}

\section{Keywords}

Protest, political participation, multiple crises, Eastern Europe, transformation

\section{Die jüngsten Protestbewegungen in Osteuropa als Indikator für eine multiple Krise?}

\section{Zusammenfassung}

Seit dem Ausbruch der Finanz- und Wirtschaftskrise 2008 sind die Staaten Osteuropas durch Austeritätspolitik, ansteigende Arbeitslosigkeit und eine zunehmende Unzufriedenheit mit der Demokratie massiv von der Krise betroffen. Vor diesem Hintergrund hat die Region eine Reihe großer Protestbewegungen erlebt. Der Artikel analysiert kritisch die aktuelle wissenschaftliche Debatte um politische Partizipation in Osteuropa. Besondere Aufmerksamkeit kommt den bisher vernachlässigten Auswirkungen der globalen ökonomischen Krise zu. Anschließend wird die Frage aufgeworfen, ob die zunehmenden Proteste auf eine tieferliegende gesellschaftliche Krise hindeuten. Damit, so schlussfolgern die Autoren, ist Osteuropa bis zu einem gewissen Grad ein Trendsetter für vergleichbare Entwicklungen in anderen Teilen Europas.

\section{Schlüsselwörter}

Protest, Politische Partizipation, Multiple Krise, Osteuropa, Transformation

The authors have declared that no competing interests exist.

The authors contributed equally to this work. 


\section{Protest in the past years in Eastern Europe}

Since the outbreak of the financial and economic crisis in 2008, Southern European countries have received both substantial scholarly and public attention. Eastern Europe, however, has not received as much attention, even though it has been equivalently affected by the crisis through intensified austerity measures, higher unemployment rates, and increasing dissatisfaction with democracy. Similar to Southern Europe, Eastern Europe has experienced several large-scale protest movements in recent years. These have included single issue protest movements, such as environmental protest in Romania (20I3) and protest against same-sex marriage in Croatia (20I4), as well as broader protest against the political elite such as in Russia (2OII-I3), Bulgaria (2OI3) or in Ukraine (20I3-20I4). Those are only a few examples of a long and diverse list of protests, which are the focus of this special issue. Although protests are not a new phenomenon in Eastern Europe, nowadays they emerge within a new international framework: the global economic crisis.

The purpose of this editorial is to critically assess the state of the art on political participation in Eastern Europe by emphasizing the still underplayed effects of the global economic crisis. Moreover, we introduce the three case studies of the special issue on Bulgaria, Russia, and Croatia. Subsequently, we discuss whether the increased number of protests indicates a deeper crisis, which has become more visible over the economic crisis. The outlook of the editorial stresses the meaning of the Eastern European protest movements in terms of democracy in the region in particular as well as for democracy in general.

\section{State of the art and its critics}

In comparison to so-called established democracies, Eastern European societies are characterized by weak political engagement in formal politics such as participating in elections, parties or other political organizations. The academic literature offers two explanations why Eastern European citizens participate less: the cultural heritage thesis and the transformation thesis. The mainstream explanation, stressing the heritage of the socialist regimes, identifies the weakness on different levels of civic and political participation. In essence, it claims that citizens share a lack of participation due to the long authoritarian experience, which caused an attitudinal legacy that is responsible for citizens' abstention from participation (Pop-Eleches/ Tucker 20I3, 46; Barnes 2006, 79). Correspondingly, weak political participation is portrayed as a direct effect of the socialist past. In fact, in many Eastern European countries, electoral participation is almost steadily on the decrease. However, declining turnout is a challenge many democracies worldwide currently face. Furthermore, diverse mass protest movements over the second half of the 2oth century in Eastern Europe, particularly at the end of the I980s, have led scholars to question the cultural heritage thesis and its diagnosis of merely negative effects stemming from socialism.

The transformation thesis offers a different view by stressing that transformation is a profound process, operating on different levels. Kornai (2006, $2 \mathrm{I} 7 \mathrm{f}$.) portrays the transformation as a "complete transformation, parallel in all spheres". The so-called "dilemma of simultaneity" (Offe I99I) incorporates various dimensions shaping politics, the economy, society, culture and so on. The political transformation, for instance the establishment of democratic institutions, procedures and civil society, did not proceed easily (Kitschelt I995). The new political elite received and partially still receives legitimacy by defining themselves as anti-communist (and often nationalistic). However, this does not necessarily include an avowal to democratic values. In terms of the economic transformation, neoliberal reforms and uneven points of departure of different societal groups caused an unequal distribution of former state property. The privatisation process, usually organized in non-transparent and corrupt procedures, produced a new class of capitalist businessmen. At the same time, the so-called "shock-therapy" led to a dramatic increase in social inequality. The neoliberal reorganisation of the welfare state, the educational system and the health sector, combined with a high level of unemployment show that the majority of Eastern European elites restricts democracy to civic rights and formal procedures. In fact, the political systems have remained highly exclusive and, thereby, impede democratic consolidation. Therefore, growing distrust in the political and economic elites and especially in institutions has emerged out of citizens' experiences with democracy after I989 (Lovell 200I). Since many people face severe financial threats, the possibilities for equal participation and representation are extremely diminished (Segert 2010, 37).

\section{The case studies}

The three case studies paint a more diverse picture of political participation in the region. This picture does not match the pessimistic perspective of the predominant cultural heritage thesis, as some parts of society engage in the public space and voice their concerns actively. In general, three protest movements, which have taken place over the last years, form the case studies of this special issue. They are diverse in terms of countries (Bulgaria, Russia, and Croatia), scope of the protest movement (local to national), po- 
litical regimes and degrees of success. However, all cases share certain features: they take place in times of economic decline and demand similar policy changes such as democratic reforms and anti-corruption measures. Further, the protest movements experience comparable reactions from the political elite. Plus, they address the mentioned gap between the official political system and its representatives on the one hand and the people on the other hand.

Michael Meznik (University Veliko Tarnovo) analyses the protests in Bulgaria in 2013. Focusing on the transformation process and the years since the country's EU accession, the author reveals manifold reasons sparking protests, in particular clientelism, corruption, and citizens' disappointment and frustration with politics since 1989. For the first time in Bulgaria's post-socialist history, a broad mass movement based on local self-organization emerged. By choosing forms of collective action, the protests showed a practical alternative to the official political system. Therefore, Meznik concludes that the year 2013 could mark a watershed for Bulgaria's future development.

Andrey Semenov (Perm State University) tackles the interconnectedness between the global economic crisis and the movement For Fair Elections in Russia. Although the immediate reason to protest was triggered by election fraud in the 20II parliamentary elections and President Vladimir Putin's 2012 re-election, the author argues that it was the worsening economic climate that influenced people's decision to engage in the nation-wide protest movement. Focusing on two regions far from the capital (Perm Krai and Tyumen Oblast), Semenov's analysis helps us to understand how specific dynamics of the protests in the Russian regions evolve and thereby also adds to case studies on Moscow or St. Petersburg.

In contrast to the aforementioned contributions, Nikola Zdunić (University of Zagreb) exclusively focuses on regional protests by analysing the development of the urban social movement Srd is Ours (Srd je naš) in the Croatian city Dubrovnik. The starting point of the article is a perceived gap between the official political system and its representatives on the one hand and the people on the other hand. According to the author, the local Right to the City movement addresses this gap by demanding direct democratic means of action (demonstrations, referendum) and forms of self-organization independent from state institution or bodies of the representative democratic system such as parties. Instead of supporting the socialist heritage thesis, the article supports the claim that current struggles in Eastern European societies are shaped by societal power relations stemming from the transformation process and the ongoing economic crisis.

\section{Protest as an indicator for multiple crises?}

In all three cases, bad governance or corruption triggered protest. They are an expression of citizens' dissatisfaction with the political elite and their actions. Drawing on Teorell et al. (2007), any form of protest is an example for "extra-representational forms" of political participation. The underlying assumption is that if citizens disagree with certain policies or the political system as such, they tend to boycott representational forms and choose channels outside of the realm of representation. Those protest movements raise the question whether the consolidation of Eastern European democracies has already been completed or whether the region experiences a growing erosion of democracy (on this issue see Knobloch's article in this journal (2OII) on post-democracy in Russia).

We argue that the roots of citizens' dissatisfaction cannot be explained by focusing only on the political sphere. Various crises take place at the same time, culminating in a profound crisis. The region faces a crisis of representation indicated by growing protest and dissatisfaction with politics. Additionally, the majority of citizens experienced the post-socialist time as a time of economic insecurity and increasing social inequality. In particular the financial and economic crisis since 2008 has marked a critical juncture after some years of almost steady economic growth since 2000. All Eastern European countries are deeply affected by the economic crisis, which has led to a decline in growth and, subsequently, economic recession in most of the countries. The reason for the vulnerability of Eastern European economies is deeply rooted in the I990s. Back then, the development of all former state socialist countries was shaped by a process of peripheralisation, meaning an increased dependency on Western economies in terms of investment, company ownership and technological know-how (Becker/Jäger 20I2). The degree of peripheralisation within the region differs. While the countries of the post-soviet space are mostly dependent on resource-extraction (Pirani 2012), the new EU member states, especially the Visegrád group (the Czech Republic, Hungary, Poland and Slovakia), were incorporated as "dependent market economies" (Nölke/Vliegenthart 2009) into the Western industrial production process. Hence, the current economic crisis is a good example of how austerity measures threaten the socio-economic basis of many citizens. Those measures, implemented by all Eastern European countries, were neither met with sufficient resistance from the public, nor did they lead to a controversial debate on the crisis and ways to overcome it (Myant et al. 2013). The increasing gap between the system of representative democracy and the daily life of the majority of the population, which is shaped by a deterioration of social standards, gives room for new 
protest movements. Finally, projects on the extraction of resources have sparked numerous conflicts all around the region, revealing contradictions between the capitalist valorisation of nature and sustainable development, in particular in the post-Soviet space (Ishkanian 2013; Jaitner 2015). These simultaneous crises (economic, political, and ecological) influence each other and thereby increase the dynamic of the crisis. Therefore, protest in the region should be perceived as "multiple crises" (on multiple crises see: Demirovic et al. 20II).

\section{Outlook: Eastern Europe as a trendsetter for Europe?}

Against the backdrop of the on-going crisis one can observe a certain alignment between Eastern and Southern Europe in terms of economic and political development. Whereas Eastern Europe has already undergone a process of peripheralisation in the I990s, for countries such as Greece and Spain the recent crisis marks a watershed in their development. In fact, apart from Latin America, Eastern Europe served as a laboratory for a neoliberal policy agenda, implementing measures, which are nowadays known as austerity-policy. To a certain degree, Eastern Europe serves as a "trendsetter" (Segert 20IO), a role model for societal developments in the West. In political terms, a deprived citizenry does not have the means to interfere and participate in democratic processes as effectively as the political and economic elites. The trendsetter thesis gives us some hints about the often-neglected ramifications of social conditions for democratic participation. The sheer number of protest movements in the past years is an indicator for the crumbling of democratic values and citizens' growing dissatisfaction with democracy. Eventually, whether democracy can be sustained might depend on whether it can lower social inequality by providing sufficient goods equally to all citizens.

\section{Literature}

Barnes, Samuel H. (2006). The Changing Political Participation of Postcommunist Citizens, in: International Journal of Sociology, 36(2), 76-98.

Becker, Joachim/Johannes Jäger (20I2). Integration in Crisis: A Regulationist Perspective on the Interaction of European Varieties of Capitalism, in: Competition and Change, Vol. I6(3), I69-87.

Demirovic, Alex/Julia Dück/Florian Becker/Pauline Bader (20II). VielfachKrise: Im finanzmarktdominierten Kapitalismus, Hamburg.
Ishkanian, Armine (2013). Civil Society, Development and Environmental Activism in Armenia, Gyumri.

Jaitner, Felix (2015). Ressourcenextraktivismus oder ReIndustrialisierung? Das russische Entwicklungsmodell im Kontext der "neuen Weltordnung“, in: Prokla I8I(I2), 513-528.

Kitschelt, Herbert (1995). Formation of Party Cleavages in Post-Communist Democracies: Theoretical Propositions, in: Party Politics, I(4), 447-472.

Knobloch, Jörn (2OII). Postdemokratie und Postsozialismus: Zur Konvergenz zweier Krisen am Beispiel Russland, in: Austrian Journal of Political Science, 40(2), 169-182.

Kornai, János (2006). The Great Transformation of Central Eastern Europe: Success and disappointment, in: Economics of Transition, I4(2), 207-244.

Lovell, David W. (200I). Trust and the Politics of Postcommunism, in: Communist and Post-Communist Studies, 34(I), 27-38.

Myant, Martin/Jan Drahokoupil/Ivan Lesay (2013). The Political Economy of Crisis Management in East-Central European Countries, in: Europe-Asia Studies, Vol. 65(3), 383-4IO.

Nölke, Andreas/Arjan Vliegenthart (2009). Enlarging the Varieties of Capitalism: The Emergence of Dependent Market Economies in Eastern Europe, in: World Politics, Vol. 6I(4), 670-702.

Offe, Claus (199I). Das Dilemma der Gleichzeitigkeit: Demokratisierung und Marktwirtschaft in Osteuropa, in: Merkur, 45(4), 279-292.

Pirani, Simon (2012). Central Asian and Caspian Gas Production and the Constraints on Export, The Oxford Institute for Energy Studies, NG 69. Internet: https://www.oxfordenergy.org/wpcms/wp-content/ uploads/2OI2/I2/NG_69.pdf (Access: 02/03/16)

Pop-Eleches, Grigore/Joshua A. Tucker (2013). Associated with the Past? Communist Legacies and Civic Participation in Post-Communist Countries, in: East European Politics \& Societies, 27(I), 45-68.

Segert, Dieter (2010). Osteuropa nach 1989: Ein Labor für die soziale Belastbarkeit unserer Demokratie?, in: WISO, 33(3), 29-42.

Teorell, Jan/Mariano Torcal/José R. Montero (2007). Political Participation: Mapping the Terrain, in: Jan van Deth/José R. Montero/Anders Westholm (eds.): Citizenship and Involvement in European Democracies: A Comparative Analysis, London, 334-357.

\section{Authors}

Tobias Spöri (1988) is a PhD candidate at the Department of Political Science at the University of Vienna. He studied Political Science and German Language and Literature in Frankfurt and Vienna. From 2013 until 2016, he 
took part in the postgraduate program "The Politics of Representation in Europe" at the Institute for Advanced Studies in Vienna. His research encompasses political participation, political socialization, Central and Eastern Europe. Latest publications: ...To be Continued? Challenging the Cultural Legacy Argument in Central and Eastern Europe (CEU Political Science Journal, 2015, IO/I-2); Militärische Operationen und externe Demokratisierung in (Post-) Konfliktstaaten (Zeitschrift für Vergleichende Politikwissenschaft, 2016 Io/2).

Felix Jaitner (1986) is a PhD candidate at the Department of Political Science at the University of Vienna. He studied European Studies in Bremen and Moscow (B.A.) and Political Science (M.A.) in Vienna. From May-August 2015 he was a research fellow at the Russian Academy of Science in Moscow. His research interests include studies on state socialism, transformation, state theory and uneven development. Latest publications: A profitable business strategy? Spent nuclear fuel and radioactive waste management in Russia (Forthcoming); Ressourcenextraktivismus oder Re-Industrialisierung? Das russische Entwicklungsmodell im Kontext der "neuen Weltordnung", Prokla I81, 12/2015. 
